\title{
PERANCANGAN DAN PEMBUATAN APLIKASI D3 TEKNIK INFORMATIKA UNS BERBASIS WEB DAN ANDROID
}

\author{
Yudho Yudhanto \\ Fakultas MIPA, Program Studi D3 Teknik Informatika \\ Universitas Negeri Sebelas Maret \\ Email: yuda@mipa.uns.ac.id \\ Dimas Sadewo Jumpa Nova \\ Fakultas MIPA, Program Studi D3 Teknik Informatika \\ Universitas Negeri Sebelas Maret \\ Email: dimasadewo.jn@gmail.com \\ Winita Sulandari \\ Fakultas MIPA, Program Studi Statistika \\ Universitas Negeri Sebelas Maret \\ Email: winita@mipa.uns.ac.id
}

\begin{abstract}
ABSTRAK
Bidang teknologi informasi merupakan salah satu pemegang peran besar dalam proses kehidupan saat ini. Dengan adanya teknologi informasi, masyarakat menjadi lebih mudah untuk mendapatkan informasi.

Sistem dan Aplikasi D3TIUNS dibuat dengan menggunakan metode waterfall, Aplikasi D3TIUNS berbasis web dibuat dengan mengunakan bahasa pemrograman PHP dengan Framework Codeigniter. Dan Aplikasi D3TI berbasis Android dibuat dengan menggunakan bahasa pemrograman java dengan tool Android Studio dengan bahasa pemrograman PHP, Java dan menggunakan Framework Codeigniter.

Perancangan yang digunakan dalam pembuatan aplikasi ini antara lain : tabel kebutuhan fungsional, use case diagram, ERD, activity diagram, Sequence diagram dan desain interface. Untuk pengujian aplikasi menggunakan metode blackbox. Hasil dari tugas akhir ini adalah terciptanya sitem informasi D3 Teknik Informatika UNS berbasis web dan aplikasi D3TI berbasis android
\end{abstract}

Kata kunci : Sistem, Informasi, Codeigniter ,Android, Android Studio, Blackbox.

\section{ABSTRACT}

Field of information technology is one of the major role holder still lives today. With the technology more easily obtain the information society.

System and Application D3TIUNS created using waterfall method, D3TIUNS web based applications created using programming language PHP with CodeIgniter Framework. And Android-based applications D3TI created using the Java programming language with Android Studio tool with the programming language php, java and using CodeIgniter Framework.

The design used in the making of this application include: table of functional requirements, use case diagram, ERD, activity diagrams, Sequence diagrams and interface design. For application testing using methods blackbox. The results of this thesis is the creation of information system D3 Informatics Engineering UNS web-based and application-based android D3TI 


\section{PENDAHULUAN}

Program Studi D3 Teknik Informatika adalah salah satu program studi yang ada di Fakultas Matematika Dan Ilmu Pengetahuan Alam. Memiliki jumlah mahasiswa kurang lebih 150 mahasiswa setiap angkatannya. Berdiri sejak tahun 2002 dengan nama D3 Ilmu komputer.

Sekitar 1900 mahasiswa telah menjadi bagian dari program studi ini. Program studi D3 Teknik Informatika mendapatkan akreditasi B. Tentu saja tidak semua orang mengetahui program studi yang terdapat di Universtas Sebelas Maret ini. Lantas bagaimana mendapatkan informasi prodi D3 Teknik Informatika dengan cara yang mudah dan tepat. Sampai saat ini Publikasi tentang informasi prodi D3 Teknik Informatika masih kurang. Ditambah lagi dengan kondisi website dari prodi ini telah off. Untuk menunjang informasi yang lebih efektif maka dibutuhkan sarana yang menunjang.

Website merupakan halaman situs sistem informasi yang dapat diakses secara cepat. Dengan adanya web maka informasi akan dengan mudah tersampaikan kepada siapa saja yang mengaksesnya. Android sudah menjadi salah satu kebutuhan bagi masyarakat umum. Khususnya untuk masyarakat Indonesia yang termasuk dalam pengguna smartphone berbasis android terbesar didunia.

Dari permasalahan yang ada muncul solusi yaitu dengan membuat sistem informasi berbasis website yang disinkronisasi dengan aplikasi client server berbasis Android untuk mempublikasi informasi program studi D3 Teknik Informatika. Dengan adanya aplikasi ini diharapkan dapat membantu masyarakat umum lebih mengenal dan mudah mendapatkan informasi program studi D3 Teknik Informatika.

Penelitian yang berhubungan dengan topik yang penulis bahas salah satunya adalah "Sistem Informasi Akademik berbasis Android pada STIMK Global Informatika Palembang" ${ }^{[1]}$ Penelitian tersebut membahas aplikasi akademik berbasis Android sebagai sarana alternatif selain melalui website. Mampu menampilkan informasi perkuliahan seperti mata kuliah, dosen, mahasiswa, nilai ujian.

Kemudian pembuatan aplikasi dengan judul "Aplikasi Android Pencarian Ustadz, Tausiyah Dan Lokasi Pengajian Dengan Sistem Sinkronasi Data” " ${ }^{2]}$ Aplikasi ini mempunyai fitur diantaranya adalah Membuat Info Ustadz Aplikasi Android pencarian ustadz, tausiyah, dan lokasi pengajian dengan sistem singkronisasi data.. Aplikasi ini dibuat dengan bahasa pemrograman java, dengan tujuan untuk mempublikasikan informasi seputar ustadz, seperti tausiyah, lokasi pengajian, serta user ustadz untuk menambahkan data tausiyah, video pengajian, mp3 pengajian, dan foto. Aplikasi android digunakan oleh user masyarakat umum untuk mendapatkan info tausiyah.

Dari latar belakang diatas dan didukung dengan bebeberapa tulisan ilmiah yang telah dikaji penulis maka solusi yang diberikan kepada instansi D3 Teknik Informatika adalah melakukan perancangan dan pembuatan Aplikasi Informasi D3TI berbasis web dan Android.

\section{METODOLOGI PENELITIAN}

Metode penelitian yang digunakan untuk menyelesaikan penelitian ini adalah waterfall models. ${ }^{[3]}$. Alur yang dilakukan adalah seperti berikut ini : 


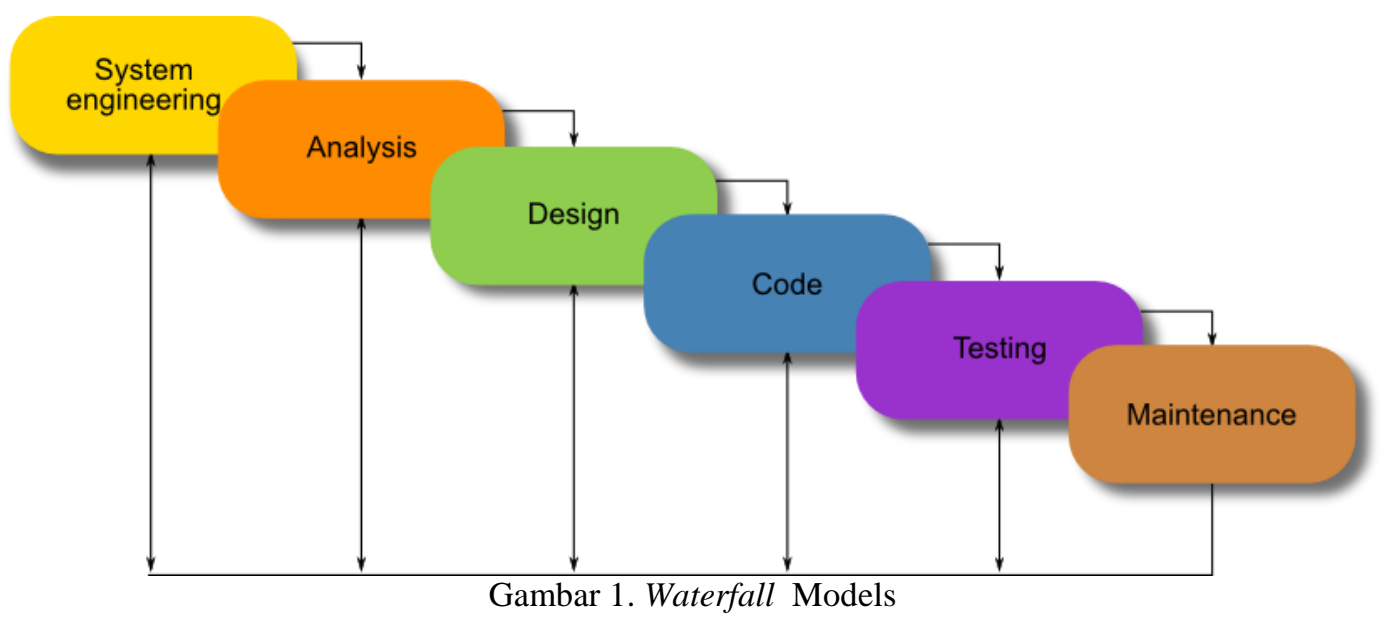
ini :

Kemudian untuk detail pelaksanaannya dibagai dalam beberapa tahap yakni seperti berikut

\subsection{Pengumpulan Data}

Pada metode pengumpulan data ini penulis melakukan studi lapangan yang terdiri dari observasi dan wawancara. Observasi dan wawancara dilakukan di program studi D3 Teknik Informatika UNS untuk mengumpulkan data mengenai proses yang terjadi dan sistem yang berjalan di program studi D3 Teknik Informatika UNS. Hasil dari pengumpulan data-data yang dibutuhkan ini untuk dianalisa dan dijadikan sebagai konsep dasar serta sebagai bahan dalam pembuatan aplikasi D3 Teknik Informatika UNS berbasis Web dan Android

\subsection{Analisa Data}

Melakukan analisa terhadap data-data yang diperoleh untuk nantinya digunakan sebagai acuan dalam merancang sistem informasi. Pada metode analisa data ini penulis juga menganalisa proses bisnis sebagai inti dari permasalahan yang dijadikan sebagai bahan dan acuan pembuatan sistem informasi.

\subsection{Desain dan Perancangan}

Setelah data dianalisa dan telah mendapatkan ide dan konsep dasar sistem, maka tahapan yang dilakukan selanjutnya adalah membuat desain yang terdiri dari tiga jenis yaitu desain proses sistem, desain database dan desain user interface.

\subsection{Desain Proses Sistem}

Desain proses sistem merupakan desain atau perancangan terhadap alur dan logika sistem. Pada desain proses sistem, disusun alur proses sistem dalam bentuk class diagram karena sistem akan dikembangkan dengan menggunakan framework yang menggunakan OOP (Object Oriented Programming).

\subsection{Desain Model Database}

Desain database merupakan desain dari sebuah tempat penyimpanan data pada sebuah sistem informasi. Desain database disusun dalam bentuk ERD (Entity Relationship Diagram). ERD merupakan hubungan dari entitas-entitas data yang memiliki atribut-atribut yang akan diwujudkan dalam bentuk tabeltabel penyimpan data.

\subsection{Desain User Interface}

Desain user interface merupakan rancangan tampilan antarmuka dari sistem informasi yang menggambarkan tata letak (layout) komponen-komponen yang dibutuhkan pada sistem informasi yang akan dibuat. Rancangan antarmuka ini dibuat semenarik mungkin namun tidak melupakan unsur kemudahan user dalam menjalankan sistem informasi. Desain user interface digunakan untuk dasar membuat tampilan sistem informasi yang nantinya akan digunakan oleh user.

\subsection{Implementasi Rancangan}


Dari rancangan yang telah dibuat, selanjutnya mengimplementasikannya melalui pembuatan sistem informasi, yaitu membuat tampilan antarmuka sesuai dengan desain user interface menggunakan pemrograman HTML, CSS, Java Script, serta bahasa pemrograman lain jika diperlukan, kemudian membuat database sistem informasi menggunakan database MySQL, serta menuliskan kode program sesuai tahapan-tahapan yang ada pada perancangan dengan menggunakan bahasa pemrograman PHP berbasis framework codeigniter.

\subsection{Pengujian Aplikasi}

Pada tahap testing ini dilakukan setelah pembuatan sistem informasi selesai, penulis melakukan pengujian terhadap sistem informasi yang telah dibuat untuk mengevaluasi hasilnya dari sistem tersebut, serta melakukan error handling, apabila terdapat error pada sistem untuk diperbaiki.

\section{HASIL DAN PEMBAHASAN}

\subsection{Proses Bisnis Aplikasi}

Aplikasi D3TIUNS terdiri dari informasi program studi D3 Teknik Informatika UNS. Informasi tersebut berasal dari pengelola yang berstatus sebagai penyedia informasi atau sekretariat program studi D3 Teknik Informatika. Syarat menjadi member, user harus terdaftar sebagai bagian dari civitas akademika D3 Teknik Informatika UNS dan sudah terdaftar di sistem untuk mendapatkan username dan password sebagai mahasiswa maupun sebagai pegawai dengan mengisi data diri. Admin akan memeriksa data apakah member tersebut benar berasal dari civitas akademika D3 Teknik Informatika UNS. Setelah berhasil menjadi member dapat melakukan kegiatan kuesioner sebagai mahasiswa.

Sedangkan pengunjung yang tidak register mendapatkan informasi umum tentang program studi D3 Teknik Informatika UNS tanpa dapat masuk kedalam sistem dapat dilihat pada dibawah ini. :

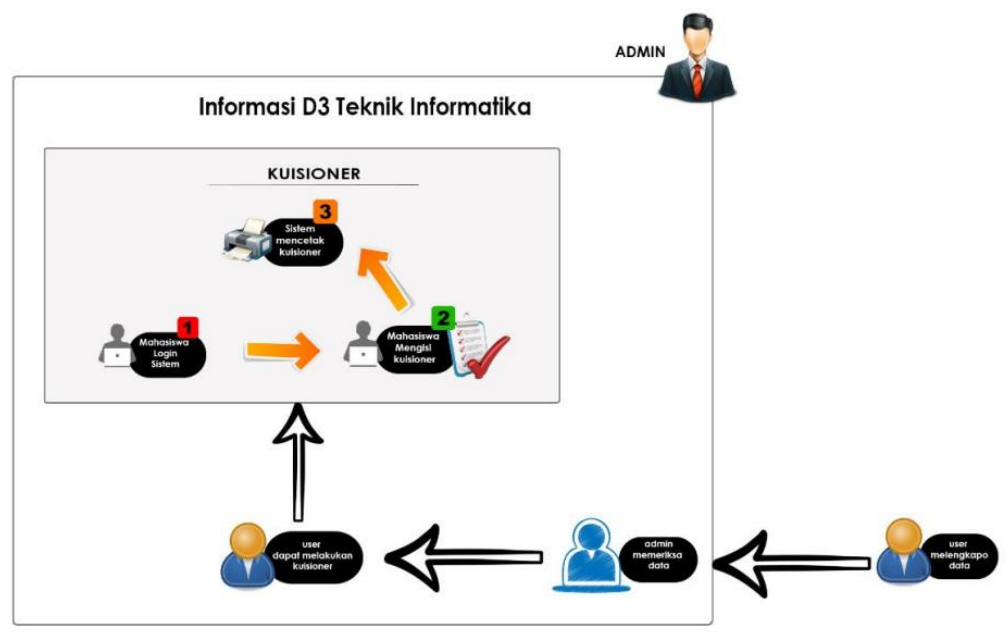

Gambar 2. Proses Bisnis Aplikasi D3TI

\subsection{Use Case}

Use Case Diagram atau diagram use case merupakan pemodelan untuk menggambarkan kelakuan (behavior) sistem yang akan dibuat. Diagram use case mendeskripsikan sebuah interaksi antara satu atau lebih aktor dengan sistem yang akan dibuat. ${ }^{[4]}$

Use Case Diagram aplikasi berbasis web terdiri dari 3 aktor. Aktor yang pertama adalah pengunjung dan aktor kedua adalah user register. User register adalah user yang telah terdaftar dalam sistem dan sudah melakukan login ke dalam aplikasi. User register meliputi: Administrator, Pegawai, dan Mahasiswa.

Berdasarkan kebutuhan fungsional aplikasi berbasis web yang telah dijelaskan, berikut adalah Use Case Diagram dari aplikasi berbasis web dapat dilihat berikut ini : 


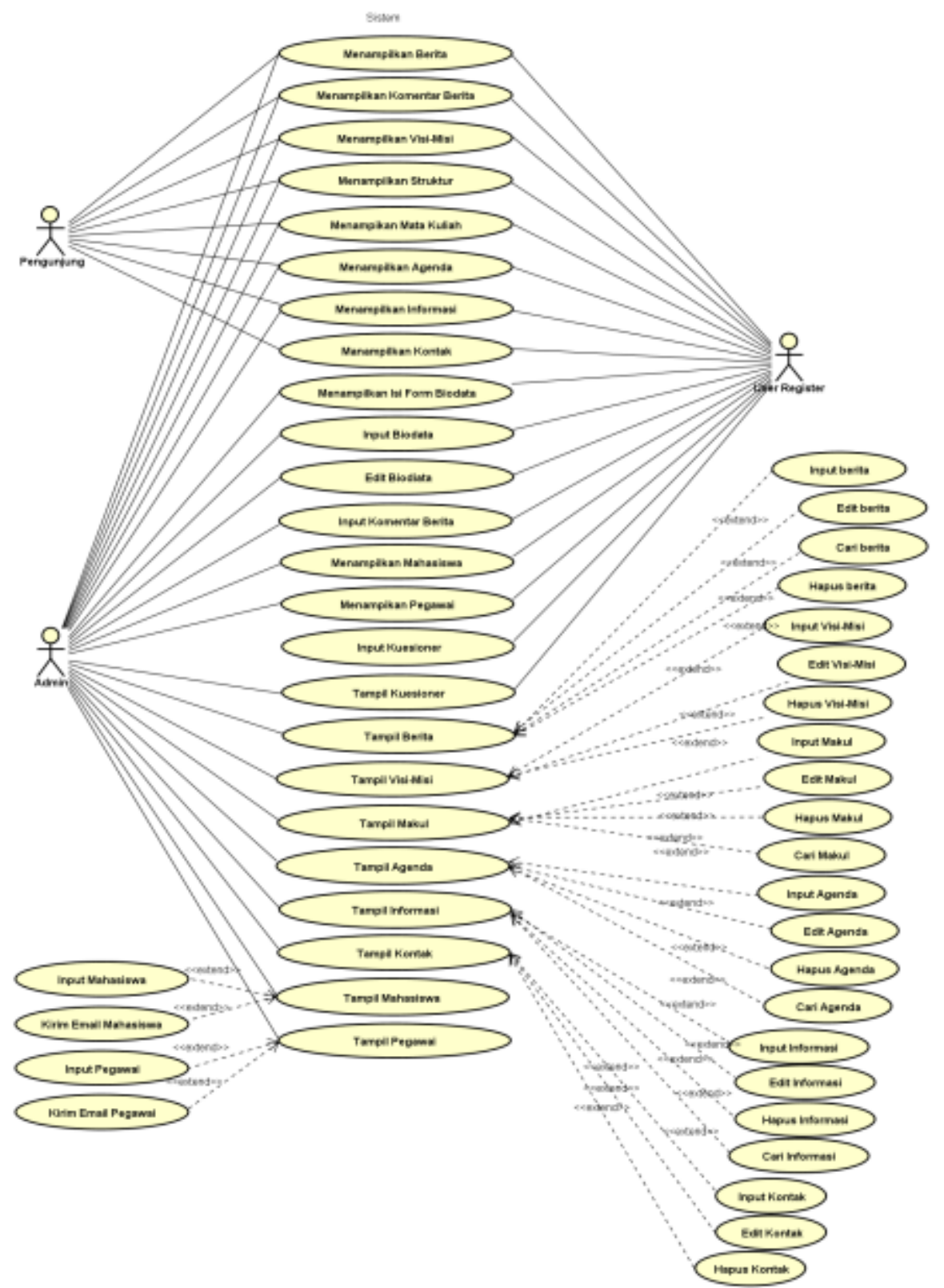

Gambar 3. Proses Use Case D3TI

\subsection{ERD}

Entity Relationship Diagram (ERD) Perancangan Dan Pembuatan Aplikasi D3 Teknik Informatika Berbasis Web Dan Android ditunjukan pada gambar 4 


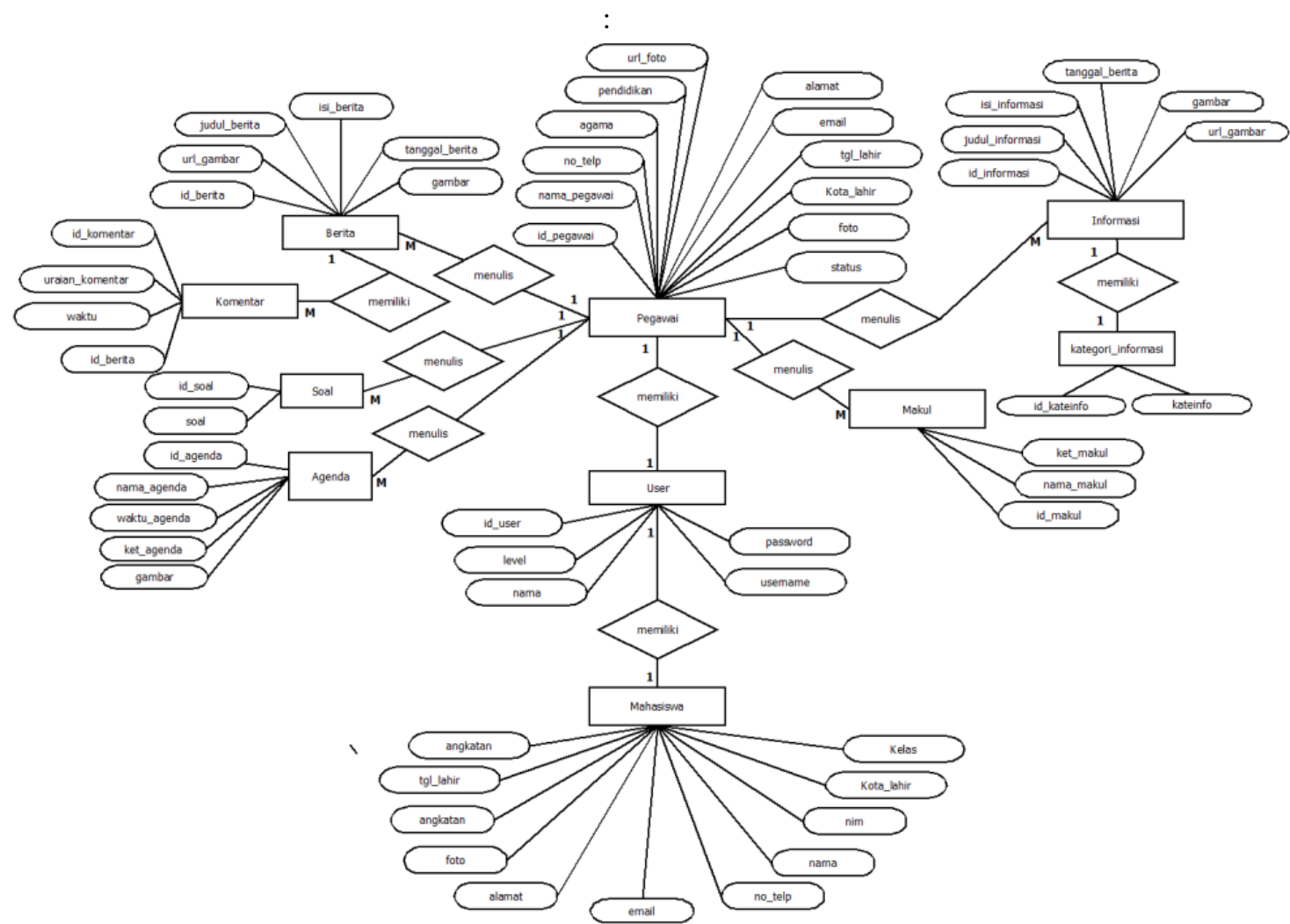

Gambar 4. ERD Aplikasi D3TI

\subsection{Relasi Tabel}

Dari desain ERD telah didapatkan desain tabel database, dimana tabel yang dihasilkan berjumlah 11 Tabel. Dengan mapping antar tabelnya ditunjuukan pada gambar 5 berikut ini : 


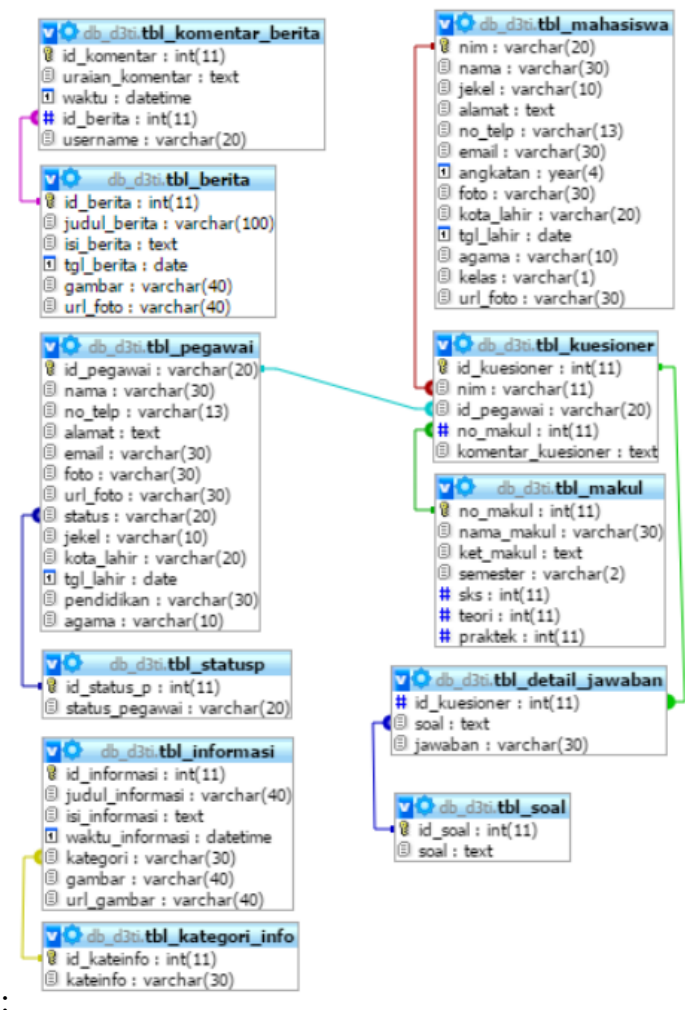

Gambar 5. Relasi Tabel Aplikasi D3TI

\subsection{User Interface}

Perancangan desain user interface aplikasi dibedakan menjadi rancangan user interface aplikasi berbasis web dan rancangan user interface aplikasi berbasis android.

\subsubsection{Web}

Pada gambar 6 menunjukkan rancangan tampilan untuk halaman depan dan halaman tampilan data.
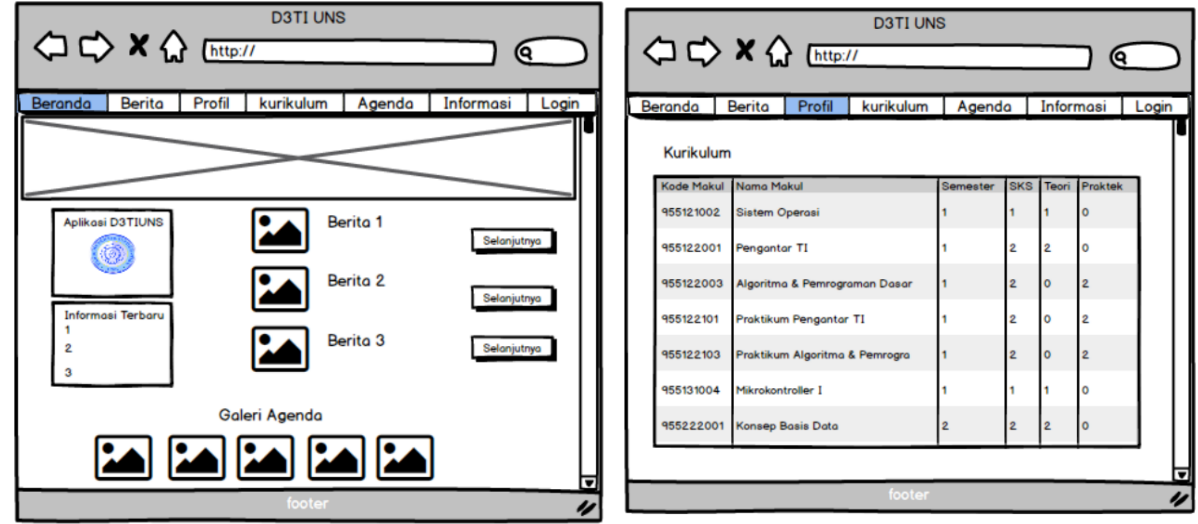

Gambar 6. Rancangan Halaman Utama

Pada gambar 7 menunjukkan rancangan tampilan untuk halaman berita dan struktur organisasi. 


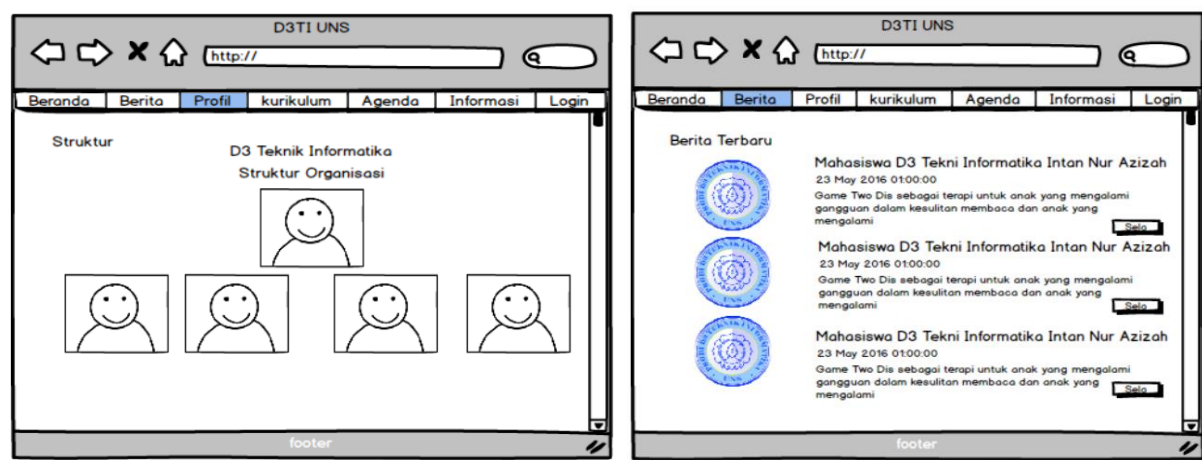

Gambar 6. Rancangan Halaman Berita dan Struktur Organisasi

Sedangkan pada gambar 7 menunjukkan implementasi tampilan tampilan untuk halaman organisasi di institusi D3TI.

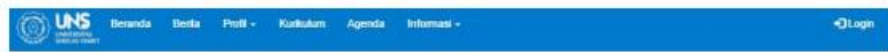

\section{Struktur Organisas}
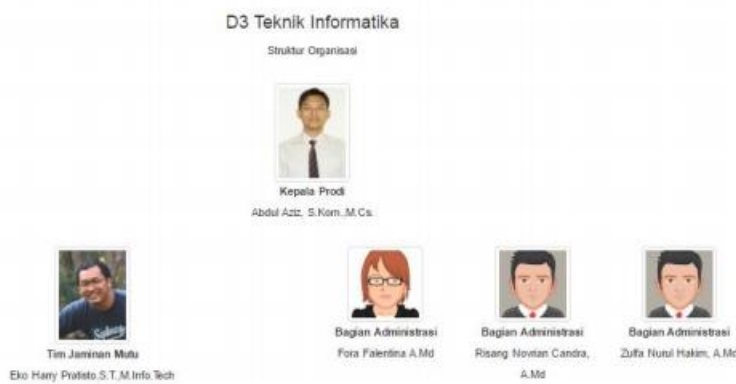

Gambar 7. Implementasi Halaman Struktur Organisasi

Kemudian pada gambar 8 menunjukkan implementasi tampilan tampilan untuk halaman berita pada aplikasi D3TI.

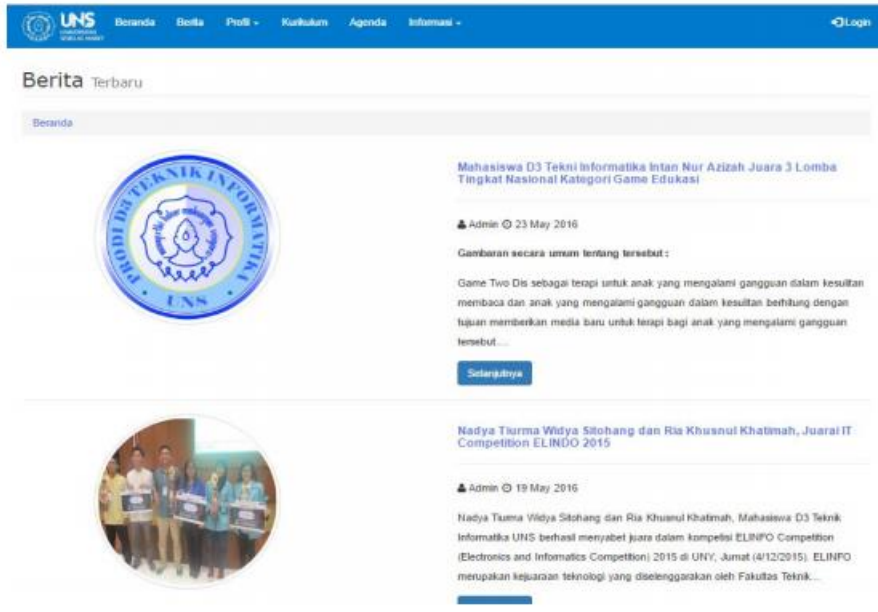

Gambar 8. Implementasi Halaman berita 


\subsubsection{Android}

Aplikasi berbasis android menyediakan halaman tampilan untuk pengunjung (guest), dan user register member yang terdiri dari mahasiswa, dosen, administrator. Berikut adalah rancangan desain interface dan penjelasan masing-masing desain.
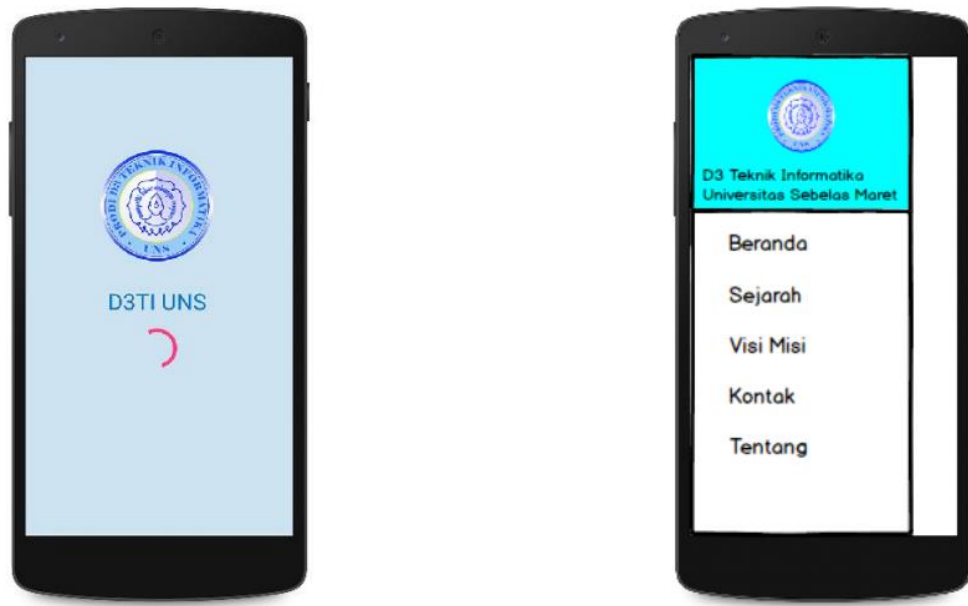

Gambar 9. Rancangan Splash dan menu Halaman Android D3TI
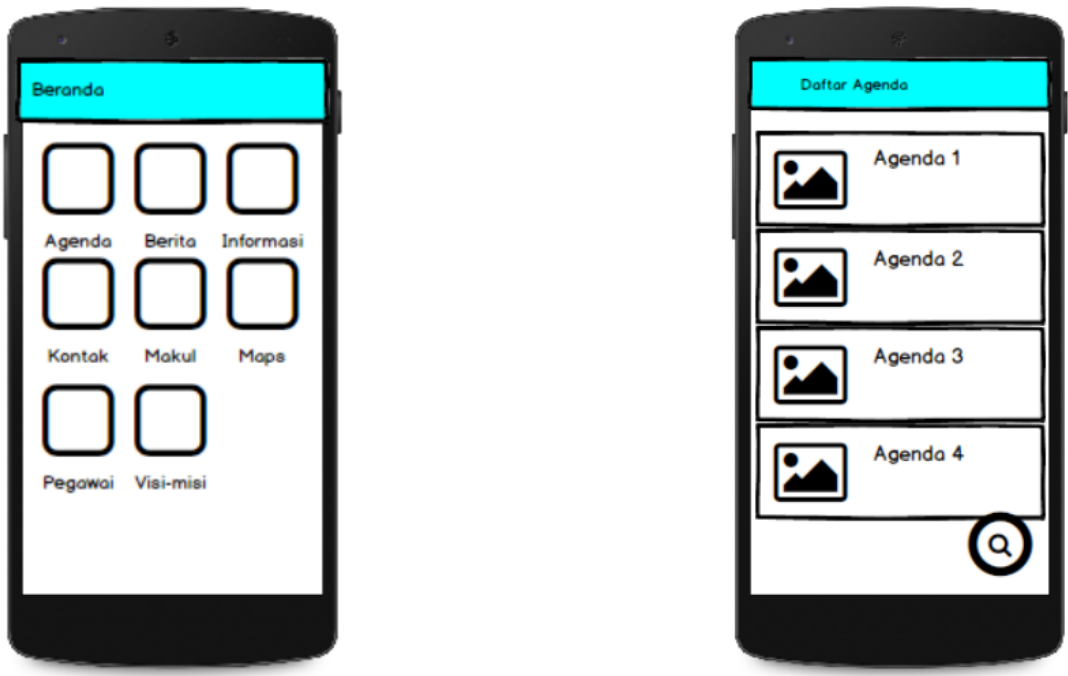

Gambar 10. Rancangan menu dan Agenda.

Kemudian pada gambar 11 menunjukkan implementasi tampilan untuk halaman berita pada aplikasi D3TI. 
Indonesian Journal of Applied Informatics, Vol.1 No. 1 November 2016

ISSN: 2548-3846

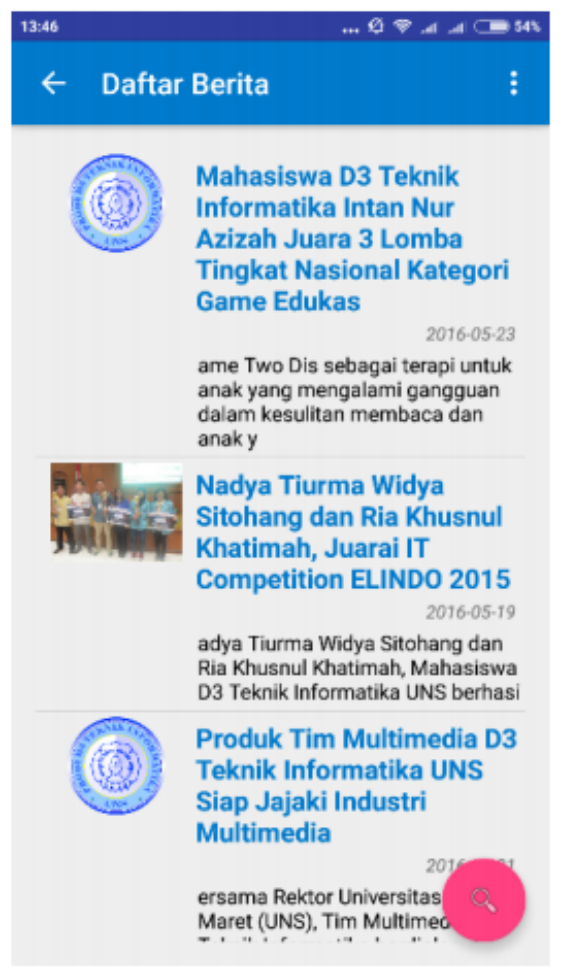

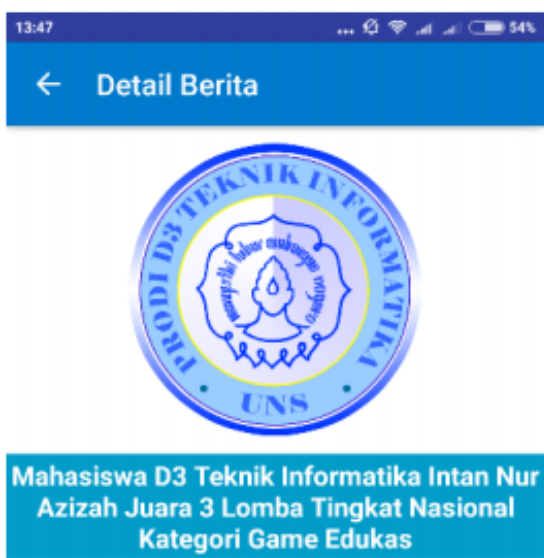

2016-05-23

Game Two Dis sebagai terapi untuk anak yang mengalami gangguan dalam kesulitan membaca dan anak yang mengalami gangguan dalam kesulitan berhitung dengan tujuan memberikan media baru untuk terapi bagi anak yang mengalami gangguan tersebut. Tahap tahap dari terapi yang akan diberikan pada game Two Dis ini adalah anak diajak untuk mengenal huruf dan angka serta dapat membedakannya juga. Kemudian anak untuk menghafalkan huruf dan angka tei yang menurut mereka sulit untuk dihafalkan.

Gambar 11. Implementasi halaman berita di Aplikasi Android

\subsection{Pengujian}

Pengujian sistem dilakukan dengan metode black box testing. Dari aplikasi yang telah dibuat maka didesain sebanyak 64 task testing, yang kesemuanya berhasil dengan baik. Berikut ini adalah contoh pengujian pada aplikasi D3TI UNS berbasis web dan android :

\begin{tabular}{lllll}
\hline No & Masukan & Hasil yang diharapkan & Hasil Pengujian & Kesimpulan \\
\hline 1 & Tambah Data & $\begin{array}{l}\text { Data masuk pasa server basis } \\
\text { data pada tabel mahasiswa }\end{array}$ & Sesuai Harapan & (v) Valid \\
\hline 2 & Ubah Data & $\begin{array}{l}\text { Data dapat diubah dan masuk } \\
\text { pada server basis data pada tabel } \\
\text { mahasiswa }\end{array}$ & Sesuai Harapan & (v) Valid \\
\hline 3 & Lihat Data & $\begin{array}{l}\text { Dapat melihat data dari basis data } \\
\text { pada tabel mahasiswa }\end{array}$ & Sesuai Harapan & (v) Valid \\
\hline
\end{tabular}

Gambar 12. Hasil testing halaman master data mahasiswa 
Kemudian untuk melakukan testing kompabilitas aplikasi terhadap peralatan yang digunakan user. Berikut ini pengujian aplikasi dengan HP Lenovo A369i, 4 inch

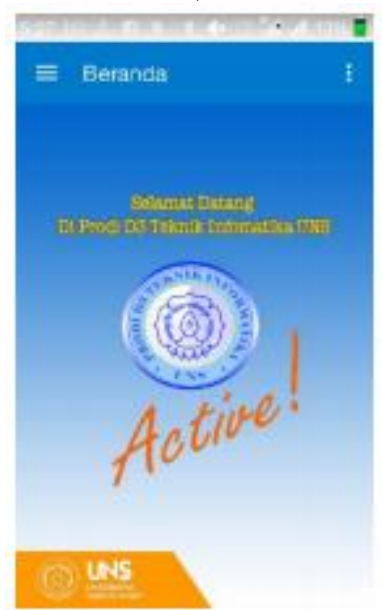

Gambar 13. Pengujian dengan Lenovo A369i

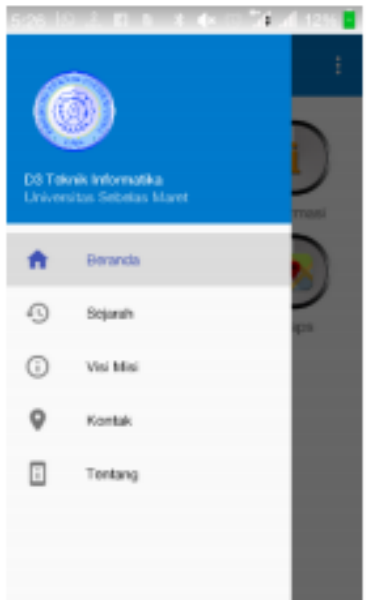

Gambar 14. Pengujian dengan Lenovo A369i
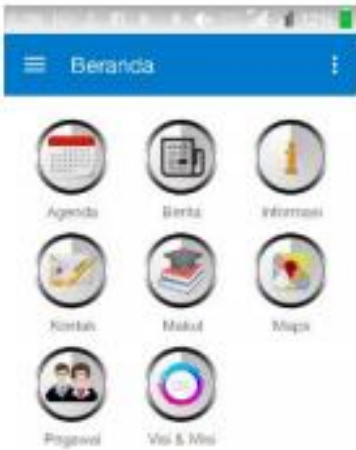

Gambar 15. Pengujian dengan Lenovo A369i 


\section{KESIMPULAN}

Kesimpulan dari perancangan dan pembuatan aplikasi D3TIUNS berbasis web dan android adalah sebagai berikut :

1. Aplikasi "D3TIUNS" berbasis web telah selesai dibuat yang memfasilitasi 3 aktor yaitu pengunjung untuk melihat dan mencari informasi, berita, agenda user register melihat data mahasiswa, pegawai, mengisi kuisioner(mahasiswa), melihat hasil kuesioner (pegawai) dan administrator untuk mengelola data master, kirim email, mengelolah kuisioner

2. Aplikasi "D3TIUNS" berbasis android telah selesai dibuat sebagai alternatif bagi pengguna untuk mencari informasi diantaranya berita terbaru, informasi terbaru, agenda terbaru, daftar mata kuliah, daftar pegawai dan tracking lokasi prodi D3

teknik Informatika dari lokasi pengguna yang memanfaatkan GPS dan Google Map.

3. Aplikasi "D3TIUNS" berbasis web dan android telah teruji kevalidan sistemnya dengan menggunakan metode pengujian blaxk box. android.

4. Aplikasi "D3TIUNS" berbasis android berjalan dengan baik pada beberapa ukuran layar device

\section{DAFTAR PUSTAKA}

[1] Achyarudin, Y. A. H. Z. (2007). Sistem informasi Akademik berbasis Android pada Stimik Global Informatika Multi Data Palembang. Stimik Multi Data Palembang

[2] Bagus Dwi Cahyo. (2012). Aplikasi Android Pencarian Ustadz, Tausiyah Dan Lokasi Pengajian Dengan Sistem Sinkronasi Data. D3TI Universitas Sebelas Maret.

[3] Pressman, R.S. 2010. Software Engineering: a practitioner's approach. New York: McGraw-Hill.

[4] Abdul Kadir. 2009. Pengenalan Sistem Informasi. Yogyakarta: Andi. 